\title{
Viden i spil
}

\section{Et bud på bibliotekernes rolle i fremtiden}

\author{
Af Jytte Nielsen
}

\begin{abstract}
Med udgangspunkt $i$ KVINFOs arbejde med opbygning af en kvindehistorisk netportal argumenterer artiklen for, at forskningsbibliotekerne i fremtiden bør påtage sig en større rolle som medspillere $i$ vidensproduktionen og i forskningsformidlingen. Forskningsbibliotekerne ligger nemlig inde med både en fagfaglig og en biblioteksfaglig ekspertise samtidig med at de har en stor viden om brugernes behov. Viden som tilsammen kalder på udvikling af nye vidensvarktøjer. KVINFOs erfaringer på dette område kan muligvis inspirere andre forskningsbiblioteker.
\end{abstract}

\section{Indledning}

I diskussionen om forskningsbibliotekernes rolle $\mathrm{i}$ fremtiden kunne det være nyttigt at se nærmere på, hvad det er for nogle biblioteks- og forskningsmæssige kompetencer og viden, som er til stede i forskningsbiblioteksmiljøerne i dag og som med fordel kan sættes i spil og udnyttes, så der opstår en synergi mellem bibliotekerne og forskningsverdenen til glæde for både studerende og forskere. De seneste år har der været stor fokus på access-aspektet, som har betydet at bibliotekernes udbud af elektroniske dokumenter er steget markant og som på sigt formentlig vil betyde, at de trykte publikationer langsomt vil blive udfaset. Det har betydet både en hurtigere og lettere tilgang til forskningsdokumenter. Til gengæld har der været mindre fokus på, hvordan man ved brug af de "gamle" biblioteksfaglige kompetencer kan få sat publikationernes vidensproduktion i forbindelse og i spil med hinanden på nye måder og på den måde være med til at styrke forskningen.

Forskningsbibliotekerne er et af de steder, hvor viden om brugernes biblioteksmæssige behov og ønsker opsamles i det daglige møde med brugerne. Nogle af de spørgsmål, der hele tiden trænger sig på er, hvordan vi kan imødekomme brugernes behov på en bedre, hurtigere og mere kvalificeret måde? Er der et mønster i brugernes henvendelser, som peger på behovet for udviklingen af nye biblioteksmæssige tiltag? Og set fra vores eget skrivebord: Er der vidensværktøjer, som vi selv mangler for at kunne imødekomme brugernes behov bedre? Og sidst men ikke

jytte.nielsen@kvinfo.dk 
mindst. Hvordan kan vi med vores både biblioteksfaglige kompetencer og brede fagfaglige indsigter bidrage til at facilitere den eksisterende viden, så den bliver brugbar og tilgængelig for flere, samtidig med at der genereres ny viden og ideer til ny forskning?

I det følgende vil jeg med udgangspunkt i mit arbejde med opbygning af KVINFOs kvindehistoriske portal give eksempler på, hvordan vi med udgangspunkt $\mathrm{i}$ brugernes efterspørgsel på viden om dansk kvindehistorie kombineret med vores egen viden på det kvindehistoriske og biblioteksfaglige område både har fået udviklet nogle nye værktøjer og skabt mulighed for at ny viden kan genereres. Først vil jeg dog kort beskrive det man kunne kalde KVINFOkonceptet, som handler om KVINFOs særlige rolle og placering som forskningsbibliotek og videnscenter.

\section{KVINFO-konceptet}

KVINFO er i dag et landsdækkende videnscenter og forskningsbibliotek, som har til opgave at formidle kvinde- og kønsforskningen til den alment interesserede offentlighed ${ }^{1}$. Med status som selvejende institution og med en grundbevilling fra Kulturministeriet på 6 mill. formidler KVINFO viden om køn både via det fysiske bibliotek og på nettet. Derudover får KVINFO bevillinger fra Integrationsministeriet og Udenrigsministeriet til dels at drive KVINFOs mentornetværk for kvinder med indvandrer- og flygtningebaggrund, dels til at igangsætte og drive projekter om køn og ligestilling i mellemøsten under "Det arabiske initiativ". Bevillinger, der tilsammen er 2/3 større end grundbevillingen til KVINFOs almene drift. Dvs. at ca. 1/4 af KVINFOs samlede bevilling i dag går til det man kunne kalde for KVINFO-classic, som bl.a. dækker driften af KVINFOs bibliotek og formidlingen på nettet.

KVINFO er således i dag meget mere og andet end et traditionelt forskningsbibliotek og videnscenter, men tilgangen til de mange aktiviteter og projekter udspringer og er fortsat forankret i KVINFOs oprindelige biblioteksfaglige viden vedr. dokumentation og formidling.

Ideen til KVINFO opstod i 1964 og kom fra Nynne Koch, kontorassistent på Det kgl. Bibliotek. Hun var interesseret i forskning om kvinder og køn og da Det kgl. Biblioteks emneindgange til litteraturen vanskeliggjorde genfindingen af publikationer inden for dette emne, påbegyndte hun udarbejdelsen af en kortbibliografi, der med eget og nyt klassifikationssystem og emneord, skulle synliggøre den eksisterende kvindeforskning (jf., Larsen, 1985). Inspirationen hentede hun bl.a. fra De Kvinnohistoriska Samlingarna i Göteborg, som var blevet etableret i slutningen af 1950'erne. Nynne Koch var ganske forudseende. For kun få år efter eksploderede efterspørgslen på viden om kvinder og køn med fremvæksten af den nye kvindebevægelse og kvindeforskningen på universiteterne.

Da KVINFO i 1987 blev oprettet som en selvejende institution med en fast bevilling på finansloven var det således en institution, der udsprang af bibliotekssektoren, men som også havde sit fundament $\mathrm{i}$ kvindebevægelsens og kvindeforskningens krav om forskningsformidling og om politisk forandring. $\mathrm{Og}$ det er dette udgangspunkt eller fundament, som fortsat er kernen i KVINFOs selvforståelse og arbejde. Og som udmønter sig i det, jeg vil kalde for et særligt KVINFO-koncept, hvis vigtigste bestanddele er:

- Institutionens unikke placering mellem forsknings- og uddannelsesinstitutionerne og den almene offentlighed

- Forskningsformidling

- Brugerne i centrum

- Mange samarbejdspartnere og stort netværk

- Institutionen arbejder med på en samfundsmæssig forandringsdagsorden

Konceptet, som gennemsyrer alle institutionens aktiviteter, er også grundlaget for etableringen af KVINFOs kvindehistoriske portal, som indeholder unikke videns- og forskningsressourcer og som i dag er et af flagskibene på www.kvinfo.dk med ca. 210.000 unikke brugere årligt.

\section{KVINFOs kvindehistoriske portal}

Arbejdet med at opbygge og formidle kvindehistoriske ressourcer har stået på i snart 10 år og portalen rummer i dag flg. 4 subsites ${ }^{2}$ :

- Kvindekilder

- Dansk Kvindebiografisk Leksikon

- Kvindepolitiske tidsskrifter 1885-1920

- Valgret 100 år. 
De 4 subsites har alle det til fælles at de for det første er et svar på konstaterede brugerbehov og for det andet at de i deres opbygning reflekterer og imødekommer forskellige brugergruppers efterspørgsel på viden.

\section{"Kvindekilder"3}

Det første skridt blev taget, da KVINFO i 2001 lancerede sitet "Kvindekilder", som består af en række webfortællinger om den danske kvindebevægelse baseret på digitalisering af et udvalgt kildemateriale. Baggrunden var de mange henvendelser fra især folke- og gymnasieelever fra hele landet, som efterspurgte viden om den danske kvindebevægelse til brug for deres opgaveskrivninger i dansk og historie. Men en yderst sparsom og sporadisk dansk forskning på feltet, stod bibliotekets personale i den situation, at de ikke havde en eksisterende kanon at henvise til, og hjælpen til brugerne bestod derfor primært i fremsendelse af kopier af artikler og oversigter udarbejdet af KVINFO selv.

"Kvindekilder", som i dag består af 11 webfortællinger og 560 digitaliserede kilder, der alle er udstyret med forklarende noter, bruges i dag i undervisningen både i grundskolen og på de højere uddannelser.

\section{Dansk Kvindebiografisk Leksikon ${ }^{4}$}

Dansk Kvindebiografisk Leksikon udkom som et trykt 3-bindsværk i 2000-2001 og var resultatet af et stort anlagt forskningsprojekt med deltagelse af en række arkiver, biblioteker og uddannelsesinstitutioner. Baggrunden for projektet var en stadigt stigende efterspørgsel på personalhistorisk viden om betydningsfulde kvinder i dansk historie, som det eksisterende Dansk Biografisk Leksikon ikke kunne honorere. Samme år som værket udkom købte KVINFO de digitale rettigheder til værket og publicerede i 2003 værket på nettet. I forbindelse med publiceringen blev samtlige 1925 biografier læst igennem og udstyret med kontrollerede termer, som muliggør kontrollerede søgninger på emne, organisation, periode og region. Derudover er det muligt at søge på navn, fødselsår og dødsår, skribent og fritekst. Udarbejdelsen af de kontrollerede termer blev til både på baggrund af en gennemlæsning af alle biografierne og på baggrund af de erfaringer bibliotekets forskningsbibliotekarer havde fra bl.a. emneindekseringer af indgåede publikationer i bibliotekets katalog.
Formålet med publiceringen af værket var:

- at give gratis og let adgang til værket for alle interesserede

- at give forskere og studerende mulighed for at foretage kontrollerede søgninger på tværs af biografierne

- at skabe fornyet forskningsinteresse for dansk kvindehistorie

Dansk Kvindebiografisk Leksikon blev straks efter publiceringen en stor publikumssucces med ca. 175.000 unikke brugere årligt. Samtidig har værket med dets mange søgeindgange en langt større anvendelighed end den trykte udgave. Muligheden for at søge kontrolleret på $\mathrm{fx}$ organisationer eller emne betyder, at det er muligt at følge spor på tværs af biografierne, som ellers ikke ville have været muligt. Og dermed opstår også muligheden for at opdage nye sammenhænge og få ny viden, som rækker langt ud over den enkelte biografi.

Med Dansk Kvindebiografisk Leksikon online har KVINFO således etableret både et nyt søgeværktøj til værket, men også åbnet for en mere forskningsbaseret og sofistikeret brug af værket.

I foråret 2009 blev Dansk Kvindebiografisk Leksikon online udvidet med en web 2.0 applikation, som gør det muligt for brugerne at kommentere på den enkelte biografi, oploade fotografier mv. Formålet er både at få ny viden i spil og at gøre leksikonet mere levende og opdateret. Brugerkommentarerne redigeres og godkendes af en redaktør.

\section{Tidsskrifter 1885-19205}

Samme år som Dansk Kvindebiografisk Leksikon online blev lanceret påbegyndtes opbygningen af et nyt kvindehistorisk site "Tidsskrifter 1885-1920" i samarbejde med Statsbiblioteket. Baggrunden var, at publiceringen af både "Kvindekilder" og Dansk Kvindebiografisk Leksikon, havde medført en markant stigning i forespørgsler vedr. den danske kvindehistorie og især om den gamle kvindebevægelse. Derudover var forhåbningen at en digital og dermed let adgang til en af hovedkilderne til den danske kvindebevægelses historie, kunne være med til at stimulere og invitere til ny forskning på området. 
Formålet med sitet var:

- at give gratis fuldtekst adgang til de 6 vigtigste kvindepolitiske tidsskrifter i perioden 1885-1920 til alle interesserede

- at tilbyde tematiske indgange til kvindehistorien til elever i grundskolen

- at give forskere og studerende mulighed for at foretage kontrollerede søgninger på tværs af tidsskrifterne

- at opmuntre til ny forskning i den gamle kvindebevægelse

Alle artikler, petitstof, annoncer mv. blev læst og lagt ind $i$ en database og $i$ den forbindelse udstyret med kontrollerede termer. Antallet af søgeindgange blev udvidet i forhold til Dansk Kvindebiografisk Leksikon, så det udover emne, professioner, organisationer, periode og region også er muligt at søge kontrolleret på teksttype, skribenternes initialer og omtalte personer. Derudover bliver debatindlæg linket sammen, så brugeren automatisk kan følge fx en debat fra start til slut.

Resultatet af det meget tidskrævende arbejde, som endnu ikke er afsluttet er, at KVINFO i dag kan tilbyde forskere og studerende et unikt værktøj til studier i den gamle kvindebevægelses historie. Et værktøj, som også har kvalificeret bibliotekets besvarelser af forespørgsler fra brugerne og som har muliggjort udarbejdelsen af tematiske indgange primært møntet på elever i grundskolen og andre mere forudsætningsløse brugere. Det første forskningsprojekt, som udnytter det digitaliserede kildemateriale, er i fuld gang. Det drejer sig om bogprojektet "Ligestillingens historie", der er forankret på KVINFO og udføres af seniorforsker og historiker Jytte Larsen. Derudover har værktøjet spillet en afgørende rolle i KVINFOs aktiviteter i forbindelse med 100-årsjubilæet for kvinders kommunale valgret i 2008.

\section{Valgret $100 \stackrel{\text { år }}{6}$}

I forbindelse med 100-året for kvinders kommunale valgret i 2008 tog KVINFOs bibliotek en række initiativer, der havde til formål at synliggøre kvinders bidrag til kommunedemokratiet. Første skridt var en folder, der blev rundsendt til arkiver, biblioteker, museer og de politiske partier, og som opfordrede til at man i de enkelte kommuner gik i gang med at udforske og formidle den lokale historie. Derudover gik biblioteket i gang med at opbygge et valgrets- site, hvis formål var at samle den eksisterende og meget spredte viden om kvinders repræsentation og kommunalpolitiske arbejde. I arbejdet med sitet, som fortsat bliver udbygget, udgør de digitaliserede kvindepolitiske tidsskrifter hovedkilden til historierne om stemmeretskampen og det første kommunalvalg $\mathrm{i}$ 1909, hvor kvinder havde mulighed for at stemme og blive valgt. Undervejs blev det tydeligt, at forskningen på området var yderst mangelfuld og begrænset og at der var behov for både vidensopsamling og ny forskning. Resultatet blev, at KVINFO i marts 2009 publicerede et online jubilæumsskrift med videnskabelige bidrag fra en række danske kønsforskere.

Formålet med udarbejdelsen af såvel valgretssitet som jubilæumsskriftet har været at:

- at synliggøre 100-årsjubilæet

- at dokumentere den eksisterende viden og publicere ny forskning om kvinder i kommunalpolitik i 100 år

- at sætte fokus på den lave kvinderepræsentation op til kommunalvalget november 2009

Jubilæumsåret viste sig at blive en succes målt i antallet af lokale arrangementer, udstillinger, foredrag, publikationer mv. landet over. Der har været en omfattende pressedækning, både i nationale og lokale medier, som i en vis udstrækning har bygget på oplysninger hentet fra valgretssitet og jubilæumsskriftet. Og der er publiceret ny forskning og skabt fornyet debat i partierne om den lave kvinderepræsentation $\mathrm{i}$ kommunalbestyrelserne.

\section{Perspektiver}

Formålet med den ovenstående detaljerede præsentation af KVINFOs arbejde med formidling af kvindehistoriske ressourcer i de seneste 10 år, har været at vise, at bibliotekssektoren har en vigtig og helt særlig rolle at spille, både når det gælder udvikling af nye vidensværktøjer og forskningsmidling til den almene offentlighed og til studerende og forskere. De nævnte eksempler rækker ud over de traditionelle biblioteksfaglige kerneområder 1) at indkøbe dokumenter 2) at registrere dokumenter i eget katalog og 3) at vejlede publikum i brug af bibliotekets ressourcer. KVINFO er selv producent af værker og databaser og dermed langt mere end en institution for fysisk dokumentlevering med supplement i form af brugerbetjening. KVINFOs aktiviteter ligger således nærmere til den 
dokumentationsfunktion, der især forbindes med traditionen fra Paul Otlet (1868-1944) og Henri Lafontaine (1854-1943). Hermed er KVINFO forhåbentligt også langt mindre sårbar overfor truslen om "library bypass" som bl.a. Open Acess stiller forskningsbiblioteker i almindelighed over for.

KVINFOs oprettelse var som tidligere nævnt baseret på en kortbibliografi, der med eget og nyt klassifikationssystem og emneord, skulle synliggøre den eksisterende kvindeforskning. Denne nye systematik og dette nye emneordssystem er interessant fordi den udgjorde en ny domænespecifik måde at organisere det samme materiale, der i forvejen befandt sig på Det kgl. Bibliotek og var ordnet efter dette biblioteks system (se også Hjørland, 2008, side 95). Den tanke at et vidensorganiserende system kan være neutralt og objektivt og tilgodese alle brugerbehov kan siges blev modbevist af Nynne Kochs system (og dets succes): Feministisk forskning havde behov for at udvikle et system, der var bedre i overensstemmelse med dette domæne. Heri ligger måske også i videre forstand en del af baggrunden for KVINFOs succes og måske en nøgle til hvordan forskningsbibliotekerne kan overleve den digitale udfordring: Ved at være en del af fagenes infrastruktur, hvor vidensproduktionen studeres og kortlægges, hvor "brugerbehov" ikke er noget abstrakt eller noget individbaseret, men noget der udvikles og forstås ud fra domænet og hvor domænets terminologi, begreber, strømninger og fagsprog er det selvfølgelige udgangspunkt for formidlingen.

Et videnscenter som KVINFO kommer i praksis til at kende sit domæne godt: Man kommer til at kende udgiverne, forfatterne (vidensproducenterne), litteraturen, dens genrer og temaer (fag- som skønlitteratur), faglige strømninger og forskellige brugergrupper. Men ikke nok med det: Man udvikler også et syn på resten af verden ud fra domænets behov, fx i form af at prioritere hvilke andre domæner, der er vigtige at overvåge og samarbejde med (og evt. have repræsenteret i institutionens egen stab).

Meget af denne viden erhverves måske som i det praktiske hverdagsarbejde som tavs eller implicit viden, men kan naturligvis være mere eller mindre baseret på eller suppleret af formelle uddannelser, undersøgelser og studier af domænet. En øget grad af tværfaglig, forskningsbaseret bibliotekspraksis kan medvirke til at skabe bedre forudsætninger (og et bedre beslutningsgrundlag) for udviklingen af fremtidige informations-, videns- og dokumentationstjenester indenfor KVINFOs område. Nogle af disse opgaver og deres mulige forskningsbasering er beskrevet i Hjørlands (2009) artikel i dette nummer. Her skal jeg kort supplere med et nøgleproblem funderet i erkendelses- og videnskabsteori. For en vidensformidlende institution skulle det synes naturligt og vigtigt at forholde sig til teori om viden. Hvilken forskel gør det, om viden forstås på den ene eller den anden måde? I KVINFOs tilfælde går dette lige til kernen af centrets identitet og funktion.

1970'ernes nye kvindeforskere definerede kvindeforskning som forskning for, om og af kvinder. Dette er en usædvanlig måde at definere et videnskabsområde på. En videnskab plejer ikke at blive defineret ved om den udføres af mænd eller kvinder (eller af bestemte sociale klasser, etniske grupper eller nationaliteter). Den plejer heller ikke at blive defineret ved sit formål (selvom fx medicin kan forstås som en videnskab med det pragmatiske formål at bekæmpe sygdomme).

Siden har kvindeforskningen udviklet sig til det, som vi i dag benævner kønsforskning, og som inddrager begge køn som både forskningssubjekter- og objekter. Kønsforskningen har i den forbindelse fået en lang række knopskydninger i form af bl.a. maskulinitetsforskning, ligestillingsforskning, seksualitetsforskning og forskning i intersektionalitet.

Selvom kønsforskningen siden 1970'erne har udviklet sig markant og også udvidet sit fokus, så står kvindebevægelsens oprindelige problematisering af den traditionelle forsknings opfattelse af objektivitet, og dens tværfaglige tilgang, fortsat ved magt.

Som det fremgår af følgende citat har kønsforskningen bidraget til erkendelsesteori og videnskabsteori:

"The central concept of feminist epistemology is that of a situated knower, and hence of situated knowledge: knowledge that reflects the particular perspectives of the subject. Feminist philosophers are interested in how gender situates knowing subjects. They have articulated three main approaches to this question: feminist standpoint theory, feminist postmodernism, and feminist empiricism. Different conceptions of how gender situates knowers also inform feminist approaches to the central pro- 
blems of the field: grounding feminist criticisms of science and feminist science, defining the proper roles of social and political values in inquiry, evaluating ideals of objectivity and rationality, and reforming structures of epistemic authority." (Anderson, 2009).

Umiddelbart lyder denne udfordring af den traditionelle videnskabelige objektivitet mærkelig. Men den er en del af en større nyorientering, der foruden kvindebevægelsen har flere andre rødder, bl.a. i en opgivelse af den logiske positivisme og en reorientering i forhold til andre traditioner. Hasle \& Drost (2009) skriver således:

"vi tror, at i hvert fald en væsentlig del af problemerne kan føres tilbage til en opfattelse af viden og information som en lineær, konstant proces, hvor man helt utilstrækkeligt definerer informationskompetencer som mønstergenkendelse, kendskab til klassifikation, søgning m.v. samt fastholdelsen af et ønske og til dels illusion om den objektive kommunikation med brugerne.

$\cdots$

(6)

Opfattelsen af bibliotekaren som den neutrale vidensformidler er forældet og har dybest set altid været en illusion. Men en illusion som var lettere at tro på med biblioteker som bogsamlinger og (forsknings)bibliotekarer som autoriteter." Hasle \& Drost (2009, side 16).

Hvis biblioteksarbejdet blot var "mønstergenkendelse" og "objektiv formidling" så kunne alle formidlingsopgaver løses én gang for alle ved en optimal algoritme a la Google. Men forskningsbibliotekerne er (dele af ) kollektive subjekter. KVINFO formidler ud fra et bestemt perspektiv. Selvom dette perspektiv stadig diskuteres, forhandles og udvikles, så er der ikke desto mindre et bestemt perspektiv, ud fra hvilke kriterier for vidensformidlingen udgår. KVINFO har - fra sin grundlæggelse - været et klart alternativ til tanken om "neutral" formidling. Og måske er dette den vigtigste erkendelse $\mathrm{i}$ visioner for fremtiden - ikke blot for KVINFO, men for forskningsbiblioteker (og andre vidensformidlende institutioner) generelt.

\section{Noter}

1. KVINFOs formål og opgaver kan man bl.a. læse om i KVINFOs vedtægter http://www.kvinfo.dk/ side/311/ og i KVINFOs resultatkontrakt 2005-08 http://www.kvinfo.dk/file.php?file=2825

2. De 4 subsites er finansieret dels for egne KVINFO-midler, dels ved støtte fra: Kulturministeriets Tips- og Lottomidler, Undervisningsministeriets programstøttemidler, Fagforeningerne Kvindeligt Arbejderforbund nu 3F, FOA, HK og SL, Statsbiblioteket, Kulturnet Danmark, Hulda Pedersens Fond, Københavns Kommune og Indenrigsministeriet.

3. Link til Kvindekilder: http://www.kvinfo.dk/ side/1050/

4. Link til Dansk Kvindebiografisk Leksikon online: http://www.kvinfo.dk/side/170/

5. Link til Tidsskrifter 1885-1920: http://www.kvinfo.dk/side/471/

6. Link til Valgret 100 år: http://www.kvinfo.dk/ side/876/

\section{Referencer}

Anderson, E (2009). Feminist Epistemology and Philosophy of Science. I: Stanford Encyclopedia of Philosophy. (Winter 2009 Edition), Edward N. Zalta (ed.). Hentet 2009-12-06 fra: http://plato.stanford. edu/entries/feminism-epistemology/

Hasle, Per \& Drost, Pernille (2009). Biblioteker - nu også med Ethos. DF-Revy, \#6 (September), 16-17. Hentet 2009-12-06 fra: http://ej.lib.cbs.dk/index.php/ dfrevy/article/view/2666/2709

Hjørland, Birger (2002). Domain analysis in information science. Eleven approaches - traditional as well as innovative. Journal of Documentation, 58(4), 422-462.

Hjørland, Birger (2008). What is Knowledge Organization (KO)? Knowledge Organization, 35(2/3), 86-101. 
Hjørland, Birger (2009). Visioner for forskningsbiblioteker - et forsknings- og uddannelsesperspektiv. Dansk Biblioteksforskning (artikel i dette nummer).

Larsen, Jytte (1985). "Et kvarter om dagen!" i: Der er en verden ved siden af verden: om Nynne Koch og kvindeforskningen: lykønskningsskrift til Nynne Koch's 70-års fødselsdag /redaktion: Merete Gerlach-Nielsen, Lene Koch, Jytte Larsen, Birgitte Possing og Nell Rasmussen. København: Forlaget April. 